\title{
„Kannski alltaf svona á bak við eyrað“: Kynjajafnréttismenntun í leikskólum
}

\author{
Sólveig Björg Pálsdóttir og Ingólfur Ásgeir Jóhannesson \\ Abstract \\ - Um höfundana \\ About the authors \\ Heimildir
}

Greinin fjallar um hvernig staðið er að kynjajafnréttismenntun elstu barna í leikskólum. Viðtöl voru tekin við sjö leikskólakennara í elstu deildum í sex leikskólum á höfuðborgarsvæðinu ásamt pví að dvelja á vettvangi til að fá innsýn í starf deildar. Úrtak var valið til að fá sem fjölbreyttastan hóp leikskóla í fleiri en einu sveitarfélagi með í rannsóknina. Greint er frá helstu niðurstöðum í premur efnisflokkum: Samfélagið og leikskólinn, kyngervi og leikefni og undirbúningur og aðstaða leikskólakennara. Í fyrsta efnisflokknum um samfélagið og leikskólann kom fram hjá viðmælendunum að hið kynjaða samfélag endurspeglaðist í leikskólastarfinu, til dæmis í kynjaskiptu búningavali. Leikskólakennararnir voru gagnrýnir á staðalímyndirnar í samfélaginu og töldu að fjölga pyrfti körlum í starfshópnum, pað skapaði meiri fjölbreytni varðandi fyrirmyndir barnanna. Leikskólakennararnir voru gagnrýnir á mótun kyngervisins hjá börnunum og töldu pað hlutverk sitt að efla gagnrýna hugsun barnanna. Í öðrum efnisflokknum, sem sneri að kyngervi og leikefni, reyndust leikskólakennararnir hafa talsvert sterka sýn á að leikefni og leikjaval festi börnin ekki í staðalímyndum. Pó bar einnig á leikefni sem sýndi hefðbundin kynhlutverk, svo sem púsl. Í priðja efnisflokknum um undirbúning og aðstöðu leikskólakennaranna komu fram einkunnarorð í nafni greinarinnar um að kynjajafnréttismenntunin væri „kannski alltaf svona á bak við eyrað“; sem markaðist af pví að gripin væru tækifæri 1 dagsins önn fremur en að fræðslan væri fyrir fram skipulögð. Rannsakendur álykta að kynjajafnréttismenntunin í leikskólunum sex hafi verið fremur ómarkviss. Hún virðist hafa verið á ábyrgð einstaklinga og var stundum ekki meðvituð. Hins vegar er áhugi til staðar, til dæmis í vali á leikefni og að baki peirri hugmynd að grípa tækifærin pegar pau gefast. Höfundar telja mikilvægt að efla stofnanalega ábyrgð á kynjajafnréttismenntun barna og að leikskólarnir purfi rækilegan stuðning til pess, ekki síst með fræðslu til starfsfólksins.

Efnisorð: Kyngervi, kynhlutverk, leikskólar, staðalímyndir

\section{Inngangur}

Staðalímyndir um kyn barna koma snemma fram. Ef rýnt er í auglýsingabæklinga fyrir börn um leikföng eru staðalímyndir um hlutverk karla og kvenna í samfélaginu áberandi. Par er hægt að sjá ryksugur, prinsessubúninga og heimilisdót fyrir stúlkur en ofurhetjubúninga, kubba og verkfæri handa drengjum. Með tiltölulega nýlegum siðum á Íslandi, svo sem barnasturtu (e. baby shower) og kynjaveislum (e. gender reveal), virðist vera lögð meiri áhersla á hvort barnið er drengur eða stúlka, jafnvel áður en pað fæðist. Rannsóknir benda til pess að staðalímyndirnar og almenn viðhorf til kynjanna um hlutverk og eiginleika peirra endurspeglist í leikskólastarfinu (sjá meðal annars Guðrúnu Öldu Harðardóttur og Gyðu Margréti Pétursdóttur, 2014; Meland og Kaltved, 2017; Dórdísi Pórðardóttur, 2012, 2015). 
Viðfangsefni greinarinnar er kynjajafnréttismenntun í leikskólum og markmiðið með rannsókninni, sem hún byggist á, var að kanna grundvöllinn fyrir pví að efla hana. Sett var fram pessi rannsóknarspurning: Hvernig er staðið að kynjajafnréttismenntun með elstu börnum í leikskólum? Rannsóknin fór fram í sex leikskólum á höfuðborgarsvæðinu.

\section{Bakgrunnur}

Í 23. grein laga um jafna stöðu og jafnan rétt kvenna og karla (nr. 10/2008) er tekið fram að jafnréttiskennsla eigi að fara fram á öllum skólastigum og að pað eigi að undirbúa „bæði kynin undir jafna pátttöku í samfélaginu“. İ sömu lögum er pess getið að eitt af markmiðum peirra sé að „breyta hefðbundnum kynjaímyndum og vinna gegn neikvæðum staðalímyndum um hlutverk kvenna og karla“ (1. grein). Einn af sex grunnpáttum menntunar er jafnrétti og samkvæmt Aðalnámskrá leikskóla 2011 (Mennta- og menningarmálaráðuneytið, 2012 eiga pessir grunnpættir að tvinnast inn í daglegt starf. Jafnrétti er mjög vítt hugtak og í aðalnámskránni er jafnrétti regnhlífarhugtak sem nær til mjög margra pátta. Kynjajafnrétti er engu að síður gerð ítarlegri skil en sumum öðrum páttum jafnréttis í textanum um grunnpætti; til dæmis er kynjafræði fyrsta fræðigreinin sem talin er upp í stuttum lista greina sem eiga að nýtast vegna jafnréttismenntunar (Mennta- og menningarmálaráðuneytið, 2012). [1]

Rannsóknaráhugi höfunda er femínískur og pví voru hugtök kynjafræðinnar notuðí rannsókninni. Femínískar kenningar gera kyngervi að miðpunkti greiningar (Rannveig Traustadóttir, 2013; Ropers-Huilman og Winters, 2011). Hér er gengið út frá pví að kyngervi sé mikilvægur páttur í öllu leikskólastarfinu, hvort sem pað er viðurkennt eða ekki. Í kaflanum er gerð grein fyrir peim hugtökum um kyngervi og orðræðu sem rannsóknin byggist á og nokkrum rannsóknum um kyngervi og leikskólastarf.

\section{Kyngervi og orðræða}

Hugtökin kyn (e. sex) og kyngervi (e. gender) eiga við um líffræðilegt kyn annars vegar og félagslega mótað kyn hins vegar. Kyngervi er talið mótast af samfélaginu og orðræðunni sem par fer fram (Butler, 1990). Mismunur kynjanna er félagslega til kominn og pví skipta hugmyndir hvers og eins samfélags um kyngervi, kvenleika og karlmennsku máli í pessu samhengi (Francis, 2006; Guðrún Alda Harðardóttir og Gyða Margrét Pétursdóttir, 2014).

Karlmennska er hugtak sem skilgreint er af samfélaginu um hvað telst vera karlmannlegt hverju sinni, pað er hvernig karl á að haga sér og líta út og hvað hann á að gera sem „sannur“ karlmaður (Ingólfur Ásgeir Jóhannesson, 2004). Ráđandi karlmennska (e. hegemonic masculinity) er hugtak sem tengist peirri kenningu að á hverjum tíma í samfélaginu sé ein tegund karlmennsku ráđandi í stigveldi karlmennskunnar sem byggist á pví að neðar í pví séu konur og undirskipaðir karlar (Connell, 2006; Gyða Margrét Pétursdóttir, 2012).

Kvenleiki er oft skilgreindur sem andstæðan við karlmennsku. Hugmyndir um kvenleika samtímans snúa að pví að sýna stúlkum og konum hvernig peim ber að líta út og haga sér samkvæmt sínu kyni (Sólveig Karvelsdóttir, 2005). Styðjandi kvenleiki (e. emphasized femininity) er systurhugtak ráðandi karlmennsku. Gyða Margrét Pétursdóttir (2012) hefur fjallað um pennan anga kvenleikans en að hennar dómi eru konur álitnar valdaminni en karlar í samfélaginu. Hegðun, framferði og tilgangur kvenna styðji karla og pær hugmyndir um karlmennsku sem eru viðteknar. Konur eiga ekki að taka of mikið pláss, pær eiga að vera kurteisar og sýna umhyggju. Ráðandi karlmennska og styðjandi kvenleiki eiga pví í gagnvirku sambandi. Andstæðan við petta er hugtakið um mengandi kvenleika (e. pariah femininity); pað er notað ef kona ögrar jafnvæginu milli ráðandi karlmennsku og styðjandi kvenleika. Konur sem sýna mengandi kvenleika eru ákveðnar, áberandi, drífandi og taka pláss. Femínismi er nátengdur mengandi kvenleika og ógnar pví stöðugleika samfélags ríkjandi karlmennsku (Gyða Margrét Pétursdóttir, 
2012; Schippers, 2007).

Rík tilhneiging er að líta á karlmennsku og kvenleika sem stöđug fyrirbæri, fremur en að pessi fyrirbæri breytist, eða að hóparnir sem eigi að sýna af sér karlmennsku (karlar) og kvenleika (konur) geti verið ólíkir innbyrðis. Staðalímynd er hugtak yfir pað pegar tilteknir eiginleikar eða hegðun eru talin einkenna ákveðinn hóp. Staðalímyndir kynjanna fela í sér viðteknar hugmyndir um eiginleika peirra eins og hið kvenlega eða hið karlmannlega. Dað er pví oftast hægt að tengja pær við eðlishyggju, sem er hugtak sem byggist á pví áliti að kynin séu „í eðli sínu“ andstæður og að karlar og konur búi yfir eðlisólíkum tilfinningum og sálfræðilegum eiginleikum (Arna H. Jónsdóttir, Steinunn H. Lárusdóttir og Dórdís Dórðardóttir, 2005). Guðný S. Guðbjörnsdóttir og Dórdís Dórðardóttir (2016) hafa bent á að skólaorðræða endurspegli oft umræðu fjölmiðla, sem leggur áherslu á eðlislægan kynjamun og hefðbundnar hugmyndir um kvenleika og karlmennsku. Mótunarhyggja er nokkurs konar andstæða eðlishyggjunnar og byggist á pví að pað sé samfélagið sem móti hegðun, eiginleika og viðhorf einstaklinga, meðal annars út frá hugmyndum um kvenleika og karlmennsku (Sólveig Karvelsdóttir, 2005).

Hugmyndir um kyngervi verða til í orðræðunni í samfélaginu. Orðræða er hugtak sem nær yfir pólitískar eða sögulegar forsendur og ágreining í tengslum við ríkjandi hugmyndafræði samfélagsins (Foucault, 1972). Hún er ferli par sem líklegra er að hugmyndir sem hana varða verði áhrifaríkari ef háttsettir einstaklingar eða valdastofnanir í samfélaginu sampykkja eða taka undir pá hugmyndafræði sem hún byggist á (Ingólfur Ásgeir Jóhannesson, 2004; Kristín Dýrfjörð, Pórður Kristinsson og Berglind Rós Magnúsdóttir, 2013). Afleiðingar orðræðu geta verið slíkar að hugmyndafræðin eða afstaðan, sem hún byggist á, séu álitnar viðteknar hugmyndir í samfélaginu. Orðræðan myndar ramma um hugsun okkar og getur orðið hluti af sjálfinu og félagslegri sýn á heiminn (Ingólfur Ásgeir Jóhannesson, 2004).

\section{Kyn og leikskólastarf}

Rannsóknir benda til pess að börn átti sig tiltölulega snemma á pví hvað felst í pví að vera drengur eða stúlka, og hegði sér pví oft innan pess kynjaramma sem pað býður upp á (Anna Elísa Hreiðarsdóttir, 2018; Hyun og Choi, 2004; Meland og Kaltved, 2017). Ríkjandi menning í barnaefni, sem börn hafa aðgang að, er talin stór páttur í kyngervismótun peirra. Teiknimyndir og ævintýri á borð við Dyrnirós, Frozen, Litlu hafmeyjuna, Hulk, Spiderman og Batman eru áhrifaríkur miðill fyrir börnin að líta inn í til pess að máta sig við ríkjandi hugmyndir um pá eiginleika sem kynin eiga að hafa (Dórdís Pórðardóttir, 2012). Petta er vitanlega ekki ókunnugt kennurum, til dæmis kom fram í rannsókn Guðnýjar S. Guðbjörnsdóttur og Steinunnar Helgu Lárusdóttur (2017) að leikskólastjórar töldu að hafa pyrfti kyn og kyngervi í huga við val á bókum og leikefni.

Orðræða um að drengir og stúlkur hagi sér og leiki sér á ólíkan hátt er áberandi. Leikur sem tileinkaður er stúlkum er oftast talinn vera rólegur og einkennast af umhyggjuhlutverkum líkt og að lita og perla eða hinn sívinsæli „mömmó“. Drengjum eru hins vegar tileinkaðir mun meiri ærslaleikir, sem einkennast af mikilli hreyfingu, til dæmis að hlaupa um eða ærslast. Ofurhetjuleikur er oftar en ekki flokkaður sem ærslaleikur öfugt við pann ímyndunarleik sem á sér stað í til dæmis heimiliskrók (sjá t.d. Guðrúnu Öldu Harðardóttur og Gyðu Margréti Pétursdóttur, 2014; Pórdísi Pórðardóttur, 2012). Dessi orðræða hefur óneitanlega áhrif á pað hvernig kennarar meta leik barnanna og hvernig peir nálgast börn í leik. Helst petta í hendur við rannsókn sem Jo Warin og Vina Adriany (2015) gerðu í Indónesíu og Svípjóð en par sást munur á milli leikskólakennara í löndunum tveimur. Hjá peim indónesísku var eðlishyggjuviðhorfið algengara og mikill munur var á pví hvernig komið var fram við börnin út frá kyni. Sænsku leikskólakennararnir, sem rætt var við, voru mun meðvitaðri í tengslum við umræðu um kyngervi og töldu mikilvægt að vinna gegn stöðluðum hugmyndum samfélagsins. Rannsakendur töldu að samfélög pessara tveggja landa hefðu áhrif á viðhorf kennaranna. Í Svípjód var mun meiri lagarammi og hefð fyrir jafnréttiskennslu, og pá sérstaklega í tengslum við kynjajafnrétti (KreitzSandberg, 2016; Sandström, Stier og Sandberg, 2013). 
Í rannsókn Guðrúnar Öldu Harðardóttur og Gyðu Margrétar Pétursdóttur (2014) kom fram hvernig pessi kynjuðu gleraugu, sem kennarar geta haft, birtast. Í greiningu peirra á upptökum í tengslum við rannsóknina var stúlkunum lýst á pann hátt að pær svifu um herbergið en drengjunum pannig að peir peyttust um, en í raun voru pau að gera sama hlutinn. Í sömu rannsókn var komið inn á tilhneigingu kennara til pess að skipta börnum upp í drengja- og stúlknahópa pegar verið var að ræða um börnin. Einu tilvikin par sem peir nefndu börn með nafni voru til pess að skilgreina pau út frá kynjahópnum. Í pessum tilvikum höfðu börnin valið sér viðfangsefni eða hegðuðu sér, að mati kennaranna, ekki innan pess ramma sem fólst í pví að vera drengur eða stúlka. Einnig var sú tilhneiging kennara sterk að koma börnum í leik með sínu kyni, og oft einungis út frá fyrir fram gefnum hugmyndum um áhuga barnsins út frá kyni pess.

Í rannsókn sinni á virðingarsessi barna ræddi Dórdís Dórðardóttir (2015) áhrif barnaefnis á stöđu peirra í barnahópnum. Par kom fram greinileg undirskipun hinna kvenlægu persóna. Drengur sem naut hæsta virðingarsess hafði mjög góða vitneskju um ofurhetjur og notaði bað óspart í samskiptum sínum við hin börnin. Kennararnir töldu ástæðuna vera meðal annars pá að hann naut mikilla vinsælda. Stúlkunni, sem var einnig í hæsta virðingarsessi, var lýst af kennurum sínum sem ljúfri og rólegri stúlku sem poldi ekki ofbeldi og var hún ekki hrifin af ofurhetjuleikjum. Hér er hægt að sjá tengingu við hugtökin ráðandi karlmennsku og styðjandi kvenleika. Рað sem nýtur mestrar virðingar innan barnahópsins og hugsanlega kennaranna einnig er í takt við ráðandi hugmyndir samfélagsins um kynin (Connell, 2006; Gyða Margrét Pétursdóttir, 2012; Ingólfur Ásgeir Jóhannesson, 2004).

Börn sjá ekki einungis staðalímyndir í barnaefni heldur einnig í samfélaginu sjálfu, og par er leikskólinn ekki undanskilinn. Pær Laufey Axelsdóttir og Gyða Margrét Pétursdóttir (2014) komust að pví að hlutverk starfsmanna í leikskólum væri oft mjög kynjaskipt. Í rannsókn sem pær framkvæmdu kom fram skýr orðræða, sem lýsti sér í jákvæðri umfjöllun um karlmennina og neikvæðari umfjöllun um kvenfólkið. Gert var mikið úr pví sem karlmennirnir tóku sér fyrir hendur á vinnustaðnum en dregið var úr mikilvægi pess sem konurnar sinntu. Dað sem einkenndi karlmennina var viss slaki, líkamleg virkni og einhvers konar töffaraskapur. Рað sem einkenndi konurnar var ofurnákvæmni, umönnun og umsjón, til dæmis við að tryggja öryggi og líkamlega umhirðu barnanna. Pessi orðræða sem hér um ræðir minnir óneitanlega á pað viðhorf sem kennarar hafa til leiks barnanna út frá kyni, sem rætt var um hér á undan. Í báđum tilvikum má greina holdgerving styðjandi kvenleikans, sem Gyða Margrét Pétursdóttir (2012) fjallaði um.

Leikskólastarf er kyrrstætt heldur einkennist pað af stöðugu próunarstarfi. Ein af hættunum við átaksverkefni og próunarstarf er pó að starf breytist einungis tímabundið (Dorgerður Einarsdóttir og Ingólfur Ásgeir Jóhannesson, 2011). Engu að síður er margt hægt að læra af próunarverkefnum eins og til dæmis starfi Iðavallar á Akureyri (Anna Elísa Hreiðarsdóttir, 2018) og Geislabaugs í Reykjavík (Jóhanna Kr. Jónsdóttir, 2015). Hluti af síðarnefnda verkefninu var áætlunargerð. Henni var ætlað að viðhalda peirri kynjajafnréttismenntun í leikskólasamfélagi Geislabaugs sem kennarar höfðu hlotið meðan á próunarverkefninu stóð.

Dekktasta próunarstarf á sviði kynjajafnréttis í leikskólum hefur pó farið fram undir forystu Margrétar Pálu Ólafsdóttur, og síðar fyrirtækis hennar, Hjallastefnunnar, par sem reknir eru margir leikskólar og einnig grunnskólar. Hjallastefnan hefur verið við lýði í meira en prjá áratugi (sjá til dæmis Margréti Pálu Ólafsdóttur, 1992) og hefur fest aðferðir sínar í sessi. Starf Hjallastefnuskóla byggist á pví, að hluta til, að kynjaskipta hópum til að styrkja bæði drengi og stúlkur á peirra eigin forsendum og er slíkt starf nefnt „uppbótarvinna“. Í „sinni einföldustu mynd er kenningin sú að stúlkur purfi meiri hvatningu og styrkingu varðandi einstaklingseiginleika heldur en drengir. Á sama hátt purfi drengir meiri pjálfun og hvatningu varðandi félagslega eiginleika“" (Hjallastefnan, e.d.).

Stofnanaleg ábyrgð hlýtur pví að vera mikilvæg pegar kemur að próunarstarfi og breytingum í págu kynjajafnréttismenntunar barna (Dorgerður Einarsdóttir og Ingólfur Ásgeir Jóhannesson, 2011). Í Svípjóð hefur kynjajafnréttishugsun í tengslum við menntun verið gert hátt undir höfði síðustu ár 
(sjá til dæmis Emilson, Folkesson og Lindberg, 2016; Sandström o.fl., 2013). Í rannsókn Susanne Kreitz-Sandberg (2016) var sýnt fram á hvernig markviss innleiðing á kynjafræðihugtökum innan mismunandi greina kennaramenntunar undirbjó kennaranema til pess að starfa með hugtökin að leiðarljósi pegar út á vettvang var komið. Sýnt var hvernig kennaranemar unnu með kyngervi og fleiri hugtök í ýmsum verkefnum í mismunandi námskeiðum í peim tilgangi að peir tileinkuðu sér notkun hugtakanna í kennslunni.

\section{Aðferð}

Ákveðið var að nota bæði vettvangsathugun og viðtöl við leikskólakennara til að kanna hvernig væri staðið að kynjajafnréttismenntun elstu barna í leikskólum.

\section{Forathugun}

Forathugun á viðtalsramma og eyðublaði fyrir vettvangsathuganir var gerð 10. og 11. janúar 2019 í leikskólum í Reykjavík. Einnig var kannað hversu langur tími á vettvangi væri skynsamlegur til að afla peirra gagna sem leitað var eftir. Viðvera á vettvangi var frá klukkan 9 til 12 báða dagana, og fylgst var með fjölbreyttu starfi.

Í kjölfar forathugunarinnar var pað metið svo að prjár klukkustundir væri hentugt viðmið fyrir hverja vettvangsathugun. Breytingar urðu á viðtalsramma í viðtalinu við deildarstjórann og á eyðublöðum vegna vettvangsathugunar og ákveðið var að fylgjast einungis með hópastarfi og samverustundum par sem samskipti kennara og barna væru meiri en í til dæmis frjálsum leik. Pótt megintilgangur með vettvangsathugun hefði verið að skapa umræðugrundvöll milli viðmælanda og rannsakanda, sem viðtölin tók (samanber Ingólf Ásgeir Jóhannesson, 2004), pá var einnig stuðst við pessi gögn í greiningu gagnanna (Kristín Loftsdóttir, 2013).

\section{Pátttakendur}

Tilaðveljapátttakendurrannsóknarinnarvarfariðyfirheimasíðurbæjarfélagaáhöfuðborgarsvæðinu. Til að leikskólarnir yrðu ólíkir og ekki valdir eftir geðpótta var Reykjavík skipt í hverfi og síðan dregnir út prír leikskólarí Reykjavík og fjórir í fjórum bæjarfélögum í nágrenni höfuðborgarinnar, pað er lagskipt slembiúrtak (Dórólfur Dórlindsson og Dorlákur Karlsson, 2013). Áður hafði verið strikað yfir pá leikskóla sem höfðu ekki upplýsingar um menntun deildarstjóra á heimasíðu, ef deildarstjórinn hafði annars konar menntun en leikskólakennaramenntun, eða ef rannsakandi ætti í faglegum eða persónulegum tengslum við einhvern í hópnum. Haft var samband við leikskólastjóra og leitað eftir leyfi peirra til að framkvæma rannsóknina í skólanum og í kjölfarið var sent kynningarbréf til leikskólastjóra og deildarstjóra. Rannsóknin fór að lokum fram í sex leikskólum í premur bæjarfélögum á höfuðborgarsvæðinu, auk forathugunarinnar, en gögnin úr henni voru ekki notuð í greiningunni. Í einum leikskólanum var, auk deildarstjórans, talað við leikskólakennara. Allir pátttakendurnir sjö eru með leyfisbréf og pví er orðið leikskólakennari notað um pá alla til einföldunar. Tveir leikskólar höfnuðu pátttöku og voru aðrir valdir í staðinn með sömu aðferð.

Dátttakendur rannsóknarinnar voru eingöngu konur sem höfðu starfað frá um 15 árum til tæplega 40 ára í leikskólum. Dær luku pví námi í leikskólafræðum á ólíkum tíma. Leikskólakennurunum sjö var úthlutað dulnefni: Berglind, Fanney, Freydís, Freyja, Linda, Ragnhildur og Silja. Fylgst var með leikskólastarfinu (hópastarfi og samverustundum) í allt að prjár klukkustundir til að fá innsýn í starf deildarinnar. Viðtölin voru yfirleitt tekin samdægurs og samhliða vettvangsathugunum á tímabilinu 28. janúar til 16. febrúar 2019 á starfsvettvangi viðmælenda. Dau voru hálfopin og tóku frá rúmum 20 mínútum upp í að vera rúmlega 70 mínútur að lengd. Pau voru hljóðrituð og afrituð orðrétt. 


\section{Greining}

Greining gagnanna fór fram með peim hætti að rannsakandi las endurtekið yfir afrit viðtalanna, skráđi pað sem pótti áhugaverðast og setti upp í töflu til að fá betri yfirsýn. Pau voru síðan lesin á ný með pessi atriði í huga og skráð var í flokka sem voru áberandi í gögnunum. Einnig voru vettvangsathuganir lesnar yfir samhliða viðtölunum og skráð pað sem pótti skipta máli. Áhorfin höfðu talsverð áhrif í viðtölunum par sem rætt var um ýmislegt sem rannsakandi hafði séð. Eftir pessa flokkun voru pemu farin að myndast, pau voru borin saman við fræðin og flokkarnir litakóðaðir. Að pví loknu var flokkað í pemun eftir bví sem hægt var út frá gögnunum (Lichtman, 2013; Merriam, 2009). Deir flokkar voru lagðir til hliðar sem ekki var talið að hægt yrði að styðja nægilega vel við með gögnum og aðrir lagaðir til. Lokaskref greiningarinnar fóru fram í samvinnu höfunda pannig að Sólveig skrifaði texta sem höfundarnir ræddu og ritstýrðu. Í pessari grein er gerð grein fyrir premur efnisflokkum með samtals 13 pemum. [2]

\section{Siðferði og réttmæeti}

Rannsóknir purfa að uppfylla ákveðnar siðferðilegar kröfur (Sigurður Kristinsson, 2013). Heiðarleiki og gegnsæi um rannsóknarferlið er eitt af lykilatriðum í eigindlegum rannsóknum til að sýna fram á trúverðugleika og réttmæti hennar (Merriam, 2009). Úrtaksaðferð pessarar rannsóknar er gagnsæ en jafnframt tilviljunarkennd til að koma í veg fyrir að eingöngu yrðu fyrir valinu leikskólar eftir einhvers konar fyrir fram gefnu áliti um jafnréttismenntun.

Áđur en rannsókn fór fram var nauðsynlegt að fá upplýst sampykki pátttakenda og fullvissa pá um að pagmælsku og nafnleyndar yrði gætt í ferlinu. Pátttakendur rannsóknarinnar voru fullorðnir einstaklingar og pví purfti ekki leyfi frá Persónuvernd. Ekki pótti nauðsynlegt af hálfu rannsakenda að kynna rannsóknina sérstaklega fyrir foreldrum par sem tilgangur áhorfsins var að fylgjast með starfi kennaranna og umhverfinu og ekkert var haft eftir börnunum.

Gildi rannsóknarinnar er samofið mikilvægi viðfangsefnisins, pað er áhuganum að auka kynjajafnréttismenntun í leikskólum. Réttmæti rannsóknarinnar byggist pví á möguleikum að bæta leikskólastarf út frá sjónarhóli kynjajafnréttis.

\section{Niðurstöður}

Fjallað verður um niðurstöður rannsóknarinnar í premur hlutum. Í fyrsta lagi verður sjónum beint að samfélagi og leikskóla, í öðru lagi að áhrifum kyngervis á starf skólanna og í priðja lagi hvernig undirbúningi er háttað og um aðstöðu leikskólakennara. Upplýsingum úr viðtölum og vettvangsathugunum er fléttað saman pegar við á. Yfirleitt er vísað til viðmælendanna með dulnefninu en í nokkrum tilvikum er nafni sleppt.

\section{Samfélagið og leikskólinn}

Eitt af pví sem sterkast kom fram hjá viðmælendum var hversu mikið hið kynjaða og kynskipta samfélag endurspeglast í leikskólastarfinu og í mörgum tilvikum einnig í pví hvernig leikskólakennararnir bregðast við í starfi sínu. Fjögur meginpemu falla undir pennan kafla: Klæðnaður barnanna, fyrirmyndir, staðalímyndir um kynhlutverk og kynjaskipting.

Viðmælendur sögðu frá dæmum um kynjaskipt búningaval, sem liti gjarnan út fyrir að vera tengt pví efni sem væri vinsælt í kvikmyndum eða sjónvarpsefni handa börnum, líkt og Spiderman og Frozen. Вæði Berglind og Silja höfðu reynslu af pví að búa til búninga í leikskólanum í tengslum við öskudag. Par kæmu fram áhrif staðalímynda á val barnanna. Berglind nefndi að pegar verið væri að undirbúa búningagerð væri pað oftast tengt pemavinnu. Með pví að tengja búningagerðina við pema væri ekki verið að koma í veg fyrir að börnin ákvæðu sjálf búninginn 
heldur væri verið að auka ímyndunarafl peirra. Algengara var að mati viðmælenda að börn veldu sér kynjaðar hugmyndir úr barnaefni, líku pví sem var nefnt hér að framan. Helst petta í hendur við aðrar rannsóknir um hversu snemma börn átta sig á pví hvað felst í pví að vera drengur eða stúlka og hegða sér innan pess ramma (Anna Elísa Hreiðarsdóttir, 2018; Hyun og Choi, 2004; Meland og Kaltved, 2017). Dví hlýtur að vera mikilvægt að ræða staðlaðar kynjaímyndir við börnin með раð аð markmiði að pau geti verið gagnrýnin á pær pegar pær birtast peim í daglegu lífi. Í próunarverkefninu Ævintýralegt jafnrétti (Anna Elísa Hreiðarsdóttir, 2018) var markvisst rætt við börnin á sérstökum fundum og pótti pátttakendum verkefnisins pað hafa mikil áhrif á getu barnanna til að vera gagnrýnin á umhverfið og málefni sem tengjast jafnrétti.

Ragnhildur og Fanney tóku fram að stúlkur sæktust eftir athygli út á fatnað sinn. Fanney lýsti pessu vel pegar hún sagðist sjá ,alveg að pað er komið í geggjað flottum kjólum og pað er bara ætlarðu ekki að segja neitt, ætlarðu ekki að segja neitt?“ Рað væri augljóst að stúlkurnar vildu fá athygli fyrir fallegan klæðnað. Dað má velta fyrir sér hvort fatnaður stúlknanna sé eins konar auður sem parf að vera sýnilegur til að hafa eitthvert vægi. Mikilvægt sé fyrir stúlkurnar að fá sampykki fyrir að fatnaðurinn sé sem fallegastur, pað veiti peim sterkari stöðu í leikskólasamfélaginu og virðingarsess í samfélagi barnanna (Pórdís Pórðardóttir, 2015).

Í viðtölum rannsóknarinnar kom sterkt fram að viðmælendum pættu fyrirmyndir mikilvægar pegar kæmi að leikskólastarfi. Að mati Lindu skiptu fyrirmyndir heima fyrir einnig miklu máli. Foreldrar í hennar hóp voru til dæmis mjög meðvitaðir um hvernig peir væru að ala börnin sín upp pegar kæmi að kynjajafnrétti. Dar nefndi hún sérstaklega mæður stúlkna. Hún tók fram að í foreldrahópnum gæetu fjölbreyttar fyrirmyndir og menntunarstig foreldranna átt hlut að máli. Einnig að foreldrarnir væru meðvitaðir um jafnréttismál og umræður um pau. Gefur petta til kynna mikilvægi umræðna við börn, hvort sem pað er heima fyrir eða í leikskólanum.

Viðmælendur nefndu einnig að pað pyrfti fleiri karla í leikskólana. Algengasta ástæðan var sú að pað yki fjölbreytni í starfi leikskólans par sem karlarnir hefðu aðra nálgun gagnvart starfinu, meðal annars vegna pess að peir lékju sér meira með börnunum og væru ekki eins fastir í hefðbundnu starfi leikskólanna og konurnar. Viðhorf sem pessi eru í samræmi við niðurstöður Laufeyjar Axelsdóttur og Gyðu Margrétar Pétursdóttur (2014) um kynjaðar væntingar starfsfólks í tveimur leikskólum. Par komu fram svipuð viðhorf um að karlkyns starfsmenn væru mun duglegri að leika við börnin og viðmælendur fundu að pví að kvenkyns starfsfólk væri fastara í skipulögðu, hefðbundnu starfi. Einnig kom fram í viðtölum rannsóknarinnar að ungir karlar sem störfuðu nú á dögum í leikskólum væru ekki síðri en ungar konur í vinnu og að peir væru settir jafnt í verkin á við aðra starfsmenn, pað er konurnar. Leikskólastarf væri unnið af mismunandi kynjum og ólíku fólki sem hlyti að hafa áhrif á pað hvernig börnin upplifðu umönnunarhlutverk. Silja sagði: „Bleyjuskipti eru ekki stelpuverk.“" Slík viðhorf bera merki um að pað sé talið mikilvægt að börn hafi pessar fyrirmyndir pó svo að viðhorf til hlutverka starfsmanna út frá kyni séu stundum ansi kynjuð. Раð ýtir undir pær vangaveltur hvort pessi viðhorf risti djúpt um stöðu fólks í samfélaginu (Gyða Margrét Pétursdóttir, 2012). Hér birtast mótsagnir: Talið var mikilvægt að vinna gegn stöðluðum kynjaímyndum en á sama tíma var umræðan á pennan veg að karlar væru mikilvægir meðal starfsfólksins.

Silja lagði áherslu á mikilvægi pess að hafa fjölbreyttar fyrirmyndir, hvort sem um kyn eða til dæmis uppruna væri að ræða. Hún sagði:

Ég held að við gerum pað einmitt með pessum fyrirmyndum í ... starfsmannahópnum og ég held ... að fyrirmyndir séu alveg ótrúlega mikilvægar í öllu starfi, pú veist. Баð er bara petta með að sjá einhvern sem að pú getur samsamað pig við eða lítur upp til ... við purfum að hafa einhverja sem að nenna að vera í fótbolta og við purfum að hafa einhverja sem vilja sitja í dúkkuleik og leika ... og við purfum einhverja sem eru flinkir аð lesa og vera fyrirmyndir pegar kemur að pví ... og pannig að við purfum svolítið að hafa allar pessar fyrirmyndir. 
Silja ræddi hér mikilvægi pess að hafa einhvern til að samsama sig við. Lykilorðið hér er einhver, ekki út frá kyni, uppruna eða öðru, heldur einhver sem hægt er að máta sig við. Í barnahópi eru nefnilega fjölbreyttir einstaklingar sem samsama sig með mismunandi hætti við ólíkt fólk, út frá kyni eða af öðrum ástæðum.

Silja ræddi pað hlutverk sem leikskólakennarar ættu að hafa í samskiptum við foreldra pegar kemur að kynjajafnréttismenntun barnanna, til dæmis með pví að ögra staðalímyndum foreldranna um áhugamál og getu barna sinna út frá líffræðilegu kyni. Hún sagði meðal annars:

Ég er í peirri stöðu að geta sagt við foreldra ... hún var rosa lin við pað að fara út, nú hefur pað lagast, hvet ykkur til að hjálpa henni með pað áfram ... Petta er stelpa sem á að taka meira pláss í umhverfi sínu ... hún má vera frakkari og ég er alltaf pínu fegin pegar að stelpur verða ópekkar ... Á sama tíma og ég er ofsalega glöð pegar ég sé strákinn sem sýnir listrænu eiginleikana og kemur ... úr fótboltafjölskyldunni. Pá finnst mér ég líka hafa pað hlutverk að segja, heyrðu veistu pað, petta er strákur sem ætti bara að fá að fara í myndlistarnám. Honum finnst leiðinlegt í fótbolta, hann sækir ekkert í pað.

Að mati Silju var petta mikilvægur páttur par sem leikskólinn og leikskólakennarar gætu og ættu jafnvel að taka meira pláss. Viðhorf Silju reyndust í samræmi við pað sem kom fram í rannsókn Annette Emilsson og félaga (2016). Kennarar töldu mikilvægt að mæta viðhorfum foreldra, sem samræmdust ekki menntunarlegum gildum skólanna um kyngervi.

Í viðtölunum komu fram margvísleg dæmi sem gáfu til kynna að viðmælendurnir væru að reyna að efla gagnrýna hugsun hjá börnunum í gegnum samræðu. Ögruðu peir ýmsum staðalímyndum í samfélaginu, svo sem með tillögum um að segja „Batgirl“ í stað „Batman“ eða að drengur gæeti verið mamma í leik. Berglind sagði:

Maður sér pað náttúrulega í leiknum pá vilja peir [drengirnir] bara vera dýr eða pabbar eða bræður ... peir ætla ekki að leika systurina eða eitthvað svoleiðis. Dau eru mjög upptekin af ... sínu kyni ... og ég hef oft ögrað peim með pví að segja svona, en af hverju ert pú ekki bara mamman? ... Í frjálsa leiknum ... par vilja pau vera sitt kyn.

Berglind sagðist ekki aðeins ögra börnunum varðandi hlutverk heldur einnig með pví að segja að engin leikföng væru „stelpudót“" eða ,strákadót““.

Hef oft tekið ... umræðu ... með stelpudótið og strákadót, pú veist, að mér finnist ekkert dót vera stelpudót frekar en ... strákadót.

Hér er hægt að sjá hvernig Berglind ögraði hugmyndum barnanna um kynhlutverk í leik og með kynjaskiptingu lita og leikfanga. Sandström og félagar (2013) fundu einnig dæmi um petta í rannsókn sinni og nefndu tæknilega aðferð (e. instrumental gender approach) par sem munur á kyni (e. sex) eða kyngervi (e. gender) var ekki talinn vera til staðar eða skipti litlu máli. Með pví að sleppa pví að ræða af dýpt muninn, sem oft sést milli drengja og stúlkna, er talað í kringum málið og pví oft varpað til baka til barnanna, og vonast er eftir að pessi kynjaða hugsun og kynjamunurinn hverfi í framtíðinni.

Áberandi var í viðtölunum umræða um kynjaskiptingu barnanna. Degar spurt var að pví hvernig unnið væri með kynjajafnrétti var oft vísað í að börnunum væri yfirleitt ekki kynjaskipt eftir verkefnum. Freyja, Linda og Ragnhildur nefndu sérstaklega að peim pætti betra að hafa börnin kynjablönduð í hópum og verkefnum. Linda sagði: „Persónulega finnst mér mjög mikilvægt аð kynin séu saman, pannig að pau læri að umgangast hvort annað.“ Freyja sagði: „Ég held аð pau læri meira hvort af öðru pegar pau eru svona í samvinnu." Pessi ummæli vekja athygli vegna pess að engin spurning í viðtalsramma rannsóknarinnar laut að kynjaskiptingu barnanna. Skýringin á pessu sjónarmiði kann að vera sú að umræðan um kynjaskiptingu Hjallastefnunnar, sem leið í kynjajafnréttismenntun barna, hefur verið áberandi. Í menntun og starfspróun 
leikskólakennaranna, sem rætt var við, virðast einnig aðrar leiðir ekki hafa verið kynntar fyrir peim til að peir gætu unnið markvisst að kynjajafnréttismenntun. Orðræðan um Hjallastefnuna myndar á pann hátt vissan ramma utan um hvað telst kynjajafnréttismenntun á leikskólum og aðrar leikskólastefnur, sem reyndar komu lítið við sögu í samtölunum, bjóða ekki upp á sambærilegar lausnir.

Orðræða flestra viðmælendanna átti pað til að vera lituð af eðlishyggju pegar talað var um leik barnanna. Freyja nefndi að stundum væri börnunum kynjaskipt svo að stúlkurnar og strákarnir gæetu fengið að leika sér í friði. Berglind talaði um að móðureðli væri kannski svo sterkt hjá stúlkum og lagði mikla áherslu á að áhugamál peirra væru ekki pau sömu og drengjanna. Vakti pessi orðræða áhuga pví pegar leið á viðtalið, og hún lýsti dæmum úr leik barnanna, kom fram að börnin væru mun blandaðri. Í viðtalinu nefndi hún hvað börn væru fordómalaus og mikilvægi pess að vera fordómalaus sem kennari. Hún taldi mikilvægt að mæta öllum börnum út frá peirra forsendum.

Degar Silja var spurð út í hvort hún fyndi mikinn mun á barnahópum eftir kyni, pá taldi hún svo vera. Hún sagðist vilja geta sagt að „,börn væru bara börn“ en að pað væru ákveðnir eiginleikar sem gætu talist kynjaðir, og velti hún pví fyrir sér hvað kæmi frá umhverfinu og hvað væri peim eðlislægt. Í sænskri rannsókn komu fram svipuð viðhorf. Kennararnir veltu fyrir sér hvað væri börnunum eðlislægt og hvað væri komið til vegna áhrifa frá umhverfinu. Fram kom viss siðklemma hvenær kennararnir stýrðu of mikið út frá hugsjónum pess að ná fram kynjahlutlausu umhverfi, og jafnvel hömluðu börnum að sinna pví sem pau hefðu áhuga á. Dað pyrfti að gæta pess að miða námið út frá einstaklingum og áhuga peirra (Emilson o.fl., 2016).

Af pessum viðhorfum að dæma, sem komu fram í pessum kafla, er hægt að sjá bæði gagnrýnin viðhorf til kynjaskiptingar og peirrar mótunar kyngervis sem börnin koma með úr samfélaginu en einnig er að finna eðlishyggjusjónarmið. Sjá má einnig pó nokkur dæmi um að pað sé ekki rétt að leikskólarnir taki staðalímyndum gagnrýnislaust. Einnig sést nokkuð skýrt að leikskólakennarar telja pað vera hlutverk sitt að efla gagnrýna hugsun hjá börnunum með umræðu.

\section{Kyngervi og leikefni}

Annar meginefnisflokkurinn, sem hér eru gerð skil, er áhrif kyngervis í leikefni leikskólanna. Leikefnið í skólunum, og allt sem að pví lýtur, er mjög fjölbreytt en hér á eftir verður fjallað um bækur, veggjaefni, kubba og púsl en einnig um hlutverkaleiki og ærslaherbergi.

Degar rætt var um bækur, sem börnin höfðu greiðan aðgang að, komu fram góðar vísbendingar um meðvitund viðmælenda um að athuga pyrfti hvers konar efni væri um að ræða, séð út frá sjónarhóli kyngervis. Viðmælendur voru sammála um að gæta pyrfti að innihaldi bókanna og ræddu pað sérstaklega ef sögurnar innihéldu staðalímyndir. Svipað kom fram í rannsókn Guðnýjar S. Guðbjörnsdóttur og Steinunnar Helgu Lárusdóttur (2017) par sem margir leikskólakennarar nefndu að hafa pyrfti sjónarmið kyngervis í huga við val á peim bókum og leikföngum sem væru börnum aðgengileg í leikskólunum. Freydís nefndi petta í viðtalinu:

Já, maður reynir að vera ekki með svona, bæði auðvitað með kynin í hlutverki ... líka ... аð pað séu ekki einhverjir kynpáttafordómar og alls konar svona sem að manni fannst kannski einu sinni allt í lagi sko ... svona eins og litli svarti Sambó ... manni fannst petta bara æðislegt ... Pangað til að maður bara, já heyrðu, petta er nú ekki að virka.

Pegar deildir viðmælendanna voru skoðaðar, meðal annars pað efni sem hékk á veggjum peirra, sáust varla dæmi um staðalímyndir. Yfirleitt báru verk barnanna pess merki að algengt væri að unnið væri með tilfinningar. Pær myndir sem voru á stafa- og tilfinningaplakötum og leiðbeiningum voru gjarnan pvert á staðalímyndir. Sem dæmi má nefna að á plakati með samhljóðum á einni deildinni var stúlka með stækkunargler að rannsaka viðfangsefni. 
Degar komið var að vali á leikefni á deildunum var algengt að pað væri talsvert úrval af kubbum sem voru, eins og Silja sagði, „svo ótrúlega ókynjað fyrirbæri í rauninni“. Um var að ræða trékubba, einingakubba, holukubba, legókubba, plúskubba og margt fleira. Flestir viðmælendanna lögðu áherslu á mikilvægi opins efniviðar. Berglind nefndi í pessu samhengi:

Leikefni í dag er svo ofboðslega opið pannig að ... pau leika, svo mikið að leika bara með teppi og kodda ... og alls konar dót ... sem er bara alveg, algjörlega endalaust opið.

Berglind nefndi einnig að раð væri ekki verið að kaupa til dæmis „Barbídót“ eða eitthvað slíkt fyrir leikskólana. Detta samrýmist niðurstöðum rannsóknar Emilson og félaga (2016) par sem svipuð viðhorf komu fram hjá nokkrum kennurum. Leikumhverfi barnanna ætti að vera kynlaust og pví til stuðnings nefndi einn af viðmælendum rannsóknarinnar að hjá peim væri ekki boðið upp á bíla eða dúkkur. Hins vegar nefndi Berglind einnig að keypt væru prinsessupúsl, sem væru meira „svona spari ... við erum ekkert að púsla á hverjum degi ...“ Einnig væri keypt til dæmis bílapúsl. Vísaði hún til pess að börnin sæktu í púslin eftir áhuga og að hún gæti séð kynjaskiptingu par. Hún sagði:

Dað hafa alveg verið keyptar inn hérna inn einhverjar prinsessubækur en líka bílabækur ... en mér finnst við einhvern veginn ... vera komin yfir petta ... petta er bara allt fyrir alla ... og petta eru púsluspil sem hún [leikskólastjórinn] kaupir rosalega mikið í Góða hirðinum og pá er petta svona pú veist kannski einhverjar prinsessur, eitthvað svona úr einhverjum ævintýrum sko ... kannski Öskubuska og ... púsluspilin pau eru svolítið svona [gerir hreyfingar og svip eins og hún sé að gefa til kynna að pað sé kynjaskipt].

Berglind undirstrikaði hér pað sjónarmið sitt að öll leikföng ættu að vera fyrir alla en pað breytti ekki endilega pví hvernig börnin sjálf veldu leikföngin eftir kyni.

Fanney nefndi að bæði púsl og bækur kæmu oft frá heimilum starfsmanna. Баð væri pá eitthvað sem peirra börn hefðu átt, og pau væru að endurnýta. Í vettvangsathugunum voru púsl hvað mest áberandi pegar kom að staðalímyndum í umhverfinu. Рað var algengt að sjá púsl með myndum af Disney-prinsessum og öđrum persónum úr teiknimyndum. Með pví er, pótt pað sé ef til vill ómeðvitað, haldið að börnunum ráðandi hugmyndum um kvenleika og karlmennsku 1 formi afpreyingarefnis sem, eins og fram hefur komið í öðrum rannsóknum, hefur áhrif innan barnahópsins (Sólveig Karvelsdóttir, 2005; Pórdís Pórðardóttir, 2015). Рað er hluti af peirra veruhætti að velja pað sem er fyrir stúlkur og pað sem er fyrir drengi. Pau hafa pegar lært pá hegðun og eru pað orðin ósjálfráð viðbrögð við áreiti úr umhverfinu og leikefninu (Connell, 2006; Gyða Margrét Pétursdóttir, 2012; Ingólfur Ásgeir Jóhannesson, 2004).

Pegar leið á viðtölin hverju sinni kom í ljós að drengir væru talsvert að leika sér í hlutverkaleik, og að hann væri yfirleitt vinsælasti leikurinn. Freyja nefndi að drengir væru jafnt og stúlkur í hlutverkaleik og að peir væru jafnvel áhugasamari en stúlkurnar. Degar hún var spurð beint út 1 hvort hún sæi mun á leik barnanna eftir kyni pá taldi hún að stúlkur væru meira í hlutverkaleik heldur en drengir. Var pað líkt og ósjálfráð viðbrögð viðmælenda pegar spurt var um leik barnanna gagngert út frá kyni peirra. Sambærilegt kom fram í rannsókn Guðrúnar Öldu Harðardóttur og Gyðu Margrétar Pétursdóttur (2014) um eiginleika sem eru eignaðir drengjum og stúlkum. Linda nefndi umræðu, sem hún hefði átt við samstarfskonu sína, um aukinn efnivið í hlutverkaleikina. Pá hefði hún spurt hvort hún ætti kjóla af dætrum sínum, sem hún gæti komið með, til að nýta í leikinn. Đá hefðu pær hins vegar staldrað við og velt fyrir sér hvers konar fatnað pær vildu hafa í boði fyrir börnin. Dær tóku umræðu um leikefnið í hlutverkaleikinn og að pað pyrfti að gæta pess að hann væri ekki kynjaður. Linda sagði:

Aðeins að bíða með pað af pví að við viljum fá inn jafnt, líka pá fyrir drengina. Pannig аð við purfum að hugsa, maður parf að hugsa ... reyna pá að hafa pað ókynjað. Раð séu bara skikkjur og grímur og eitthvað pess háttar. En ekki að ... við séum ekki með hjúkrunarkonubúninga og læknabúninga. 
Parna má sjá hvernig Linda virtist meðvitað velta fyrir sér hvers konar efniviður væri í boði. Svipar pessum vangaveltum til peirra sem komu fram í rannsókn Emilson og félaga (2016) um leikumhverfi barnanna, аð pað ætti að vera kynlaust.

Áberandi var að viðmælendum var umhugað um að mæta pörfum allra barna og að pað væri mikilvægt að mæta peim út frá einstaklingssjónarmiðum. Einn leikskólakennaranna lagði mikla áherslu á pað. Á deildinni hjá henni voru til að mynda bókstafir á veggjum og gólfum. Hún sagði að hjá peim væri sérstakt herbergi tileinkað ærslum og mikið lagt upp úr pví að vinna verkefni deildarinnar á sem fjölbreyttastan hátt til að mæta pörfum allra barna. Nefndi hún til dæmis að sér pætti mikilvægt að hafa pláss fyrir ærslin og að pað væri mikilvægt að veita stúlkunum einnig rými fyrir slíkt. Margt í viðtalinu við pennan leikskólakennara bendir til pess að unnið hafi verið að pví að jafna aðgengi kynjanna að ýmsum verkefnum, til dæmis með pví að nota meðvitaðar leiðir til pess að auka áhuga barnanna á viðfangsefnum par sem kynjahalli var til staðar. Dæmi um slíkt var að markvisst var unnið að pví að fá strákana meira inn í myndlistina. Deildarstarfsmönnum póttu peir lítið sækja í hana en pað væri einnig mikilvægt fyrir drengina að pjálfa pá færni, svo sem fínhreyfingar, pannig að rétt væri að hvetja pá í myndlist. Ef stúlkurnar höfðu verið áberandi minna í ærslaherberginu var drengjunum stundum gefið frí frá pví svæði til að gefa stúlkunum færi á að vera par. Рað var frjálst að fara í herbergið en pað voru fjöldatakmarkanir. Leikskólakennarinn nefndi að drengirnir væru oft fyrri til og ágengari að komast á svæðið. Meðvitað var hugað að pví að stúlkurnar færu ekki á mis við ærslin. Dæmin hér að framan sýna fram á hvernig starfsfólk pessarar deildar fylgdist með börnunum með kynjahalla að leiðarljósi. Unnið var markvisst að pví að bjóða upp á umhverfi sem ýtti undir pað að börnin hefðu jafnt aðgengi að leiksvæðum en einnig var reynt að vekja áhuga á efnivið par sem starfsfólkið taldi að mikill kynjahalli væri til staðar (Lög um jafna stöðu og jafnan rétt kvenna og karla nr. 10/2008; Mennta- og menningarmálaráđuneytið, 2012).

\section{Undirbúningur og aðstaða leikskólakennara}

Spurt var um hvernig væri staðið að kynjajafnréttisfræðslu og komu fram nokkur pemu hvað pað varðar, einkum meðvitund og mannauður, jafnréttisstefna og ákall um fræðslu fyrir leikskólakennarana.

Degar spurt var um hvernig kynjajafnrétti væri fléttað inn í daglegt starf var í flestum tilfellum talað um að pað væri „,kannski alltaf svona á bak við eyrað“, eins og Linda orðaði pað. Dótt ekki væri unnið markvisst með pennan pátt væru kennararnir meðvitaðir um jafnrétti kynjanna og pví væru tækifærin gripin pegar pau kæmu upp í barnahópnum. Silja nefndi að í pessu samhengi, sem og mörgu öðru í leikskólanum, pyrfti að grípa tækifærin með börnunum pegar pau gæfust. Dæmi úr viðtölunum um slíka umræðu voru varðandi stelpu- og strákaleikföng, liti, innihald bóka, val á hlutverkum í leik og hverjir mættu vera með. Ragnhildur sagði:

Oft er maður kannski ekkert að blanda sér inn í ... allt sem að kemur upp hjá krökkunum ... en við nefnum alveg pú veist, pað hafa alveg verið strákar sem vilja vera í pilsum og bleikum fötum og allt petta ... við ræðum petta svolítið við pau ... að allir litir eru allra ... og sérstaklega litirnir og einmitt leikurinn og að vera leika við stelpu og strák ... Við ræðum petta svolítið við pau.

Slíkar hversdagslegar samræður töldu viðmælendur vera bestu leiðina til að ræða hluti sem peir töldu vera einn pátt í kynjajafnréttismenntun barna.

Silja undirstrikaði að pýðingarmikið væri að leggja áherslu á „,meðvitund“ um viðfangsefni. Pá væri bæði hægt að sjá hvað væri vel gert en einnig færi maður ósjálfrátt að vinna meira með pað. Dess vegna væri mikilvægt að leggja áherslu á pessa samræðu. Dekking býr til vissan grunn sem hægt er að vinna út frá. Ef kennarar pekkja vel hugtök kynjafræðinnar hlýtur pað að stuðla að pví að peir sjái betur tækifærin sem parf að grípa. Samkvæmt rannsókn Kreitz-Sandberg (2016) 
er mikilvægt að pekking á hugtökum kynjafræðinnar sé til staðar til pess að leikskólakennararnir geti unnið markvisst með pau í starfi sínu. Detta helst í hendur við viðhorf Silju um meðvitund í tengslum við viðfangsefni kynjajafnréttis.

Freyja nefndi að pað hefði til dæmis verið rætt á starfsmannafundi að fara yfir bækurnar og að passa að pær væru ekki ,kynjaskiptar“, eins og hún orðaði pað. Líkt og kom fram hér að framan voru engar bækur með áberandi staðalímyndum, sem börnin höfðu greiðan aðgang að. Í viðtali við Silju kom einnig fram mikilvægi pessarar umræðu, og að starfsmenn væru samstíga í starfi. Silja sagði meðal annars:

Parna er í rauninni mannauðurinn að nýtast okkur að einmitt hlutirnir gerast svolítið sjálfkrafa ... vegna pess аð раð er ... grunnmeðvitund í gangi um að hlutirnir eigi að vera með ákveðnum hætti eða við viljum hafa petta svona eða hinsegin ... pó að við tölum ekki reglulega um pað, að pá er pað samt ... undirliggjandi.

Hugmyndir leikskólakennaranna um kyngervi barnanna birtust mjög greinilega í pví sem fram kom í viðtölunum. Deir voru gagnrýnir á staðalímyndir á sama tíma og pað sáust greinileg merki um að viðteknar hugmyndir um kvenleika og karlmennsku hefðu blandast fremur greiðlega inn í starf leikskólans, til dæmis með afpreyingarefni fyrir börn. Petta er alveg í samræmi við pá skoðun að ríkjandi pættir í pessari menningu séu taldir eiga mikinn pátt í kyngervismótun barna og að peir séu birtingarmynd kvenlægra og karllægra eiginleika sem samfélagið heldur að börnum (Pórdís Pórðardóttir, 2012).

Í viðtölunum kom fram mjög sterkt ákall um meiri fræðslu. Dað einkenndi samræður við kennarana áður en viðtölin hófust að viðmælendur voru ansi óöruggir varðandi viðfangsefnið og töldu sig oft ekki vera að vinna með kynjajafnréttismenntun í daglegu starfi. Petta samrýmist pví sem kom fram í rannsókn Guðnýjar S. Guðbjörnsdóttur og Pórdísar Pórðardóttur (2016) um takmarkaða pekkingu kennaranema á grundvallarhugtökum tengdum kynjajafnrétti. Einnig helst petta í hendur við matið á próunarverkefninu Jafnréttisfrceðsla i leik- og grunnskólum par sem rætt var um litla pekkingu kennaranna á málefninu (Arnfríður Aðalsteinsdóttir, 2010).

Undir lok flestra viðtalanna kom hins vegar í ljós að viðmælendur voru að gera margt í starfi sínu sem hægt væri að tengja kynjajafnréttismenntun. Áberandi var að pað sem var gert virtist ómeðvitað og jafnvel ekki hugsað sem kynjajafnréttismenntun. Freyja nefndi að hún hefði lesið sér til um efnið áður en rannsakandi kom. Hún hefði ekki verið alveg viss um hvað væri verið að skoða og ræða. Silja nefndi hvað væri hægt að gera til að auka fræðslu um petta viðfangsefni. Hún sagði að sveitarfélagið sem hún starfaði hjá væri að byrja aftur með nýliðanámskeið. Á pví verður farið yfir helstu pætti sem tengjast leikskólastarfi, til dæmis verður fræðsla um leik og proska barna. Um var að ræða námskeið sem ætlað var ófaglærðu starfsfólki, og ætti fræðsla sem pessi heima par að hennar mati. Bæði Freydís og Freyja nefndu mikilvægi pess að vera í sífelldri próun í starfi og að pað væri mikilvægt að staðna ekki. Fræðsla í kynjajafnrétti væri hluti af pví ferli og væri á pann hátt í takt við pjóðfélagsbreytingar. Samkvæmt orðum peirra sáu pær gildi pess að sveitarfélögin byðu upp á slíka fræðslu. Tillögu Silju var beint að ófaglærðu starfsfólki en orð Freyju og Freydísar gáfu einnig til kynna mikilvægi pess að bjóða upp á slíka fræðslu í endurmenntun fyrir leikskólakennara.

Linda lagði fram pá hugmynd að útbúið yrði einhvers konar námsefni eða „pakkar“, sem leikskólarnir hefðu aðgang að. Detta sýndi að hvaða leyti Linda taldi mögulegt að nálgast viðfangsefni kynjajafnréttismenntunar og flétta pví inn í daglegt starf leikskólans. Рað pyrfti pekkingu og með aukinni fræðslu gætu leikskólakennarar tileinkað sér pessi vinnubrögð í starfi. Rannsóknir bentu til pess að pekking á hugtökum kynjafræðinnar skipti sköpum ef vinna ætti markvisst með pennan anga jafnréttiskennslu og ef vinna ætti með kynjajafnrétti sem hluta af okkar samfélagslegu og menntunarlegu gildum (sjá til dæmis Emilson o.fl., 2016; KreitzSandberg, 2016; Sandström o.fl., 2013). 
Ef leikskólakennarar eiga að geta unnið markvisst að kynjajafnréttismenntun barna pá er nauðsynlegt að peir hafi góðan grunn í kynjafræði. Рað kom hins vegar nokkuð skýrt fram í viðtölunum að pað vantaði pó nokkuð upp á menntun og símenntun kennara. Að hluta til var ástæðan sú að nokkuð var um liðið síðan kennararnir luku námi sínu. Á hinn bóginn var einnig áberandi að fæstir vissu hvar hægt væri að sækja starfspróunarnámskeið um kynjafræði. Flestir töldu að slíkt stæði til boða en peir hefðu ekki orðið varir við pað. Linda sagði:

Deir eru rosalega duglegir að bjóða alls konar fræðslu ... en pað hefur ekki alla vega hoppað í andlitið á mér síðan ég byrjaði.

Fanney sagði:

Ég man ekki eftir pví að hafa farið. Dað eru eflaust einhver svona símenntunarnámskeið ... um akkúrat petta ... en ég man ekki eftir pví að pað hafi einhver farið á pað nýlega sko.

Ef petta er dregið saman, pá vantaði að mati viðmælenda aðgengi að námsefni og fræðslu svo hægt væri að flétta kynjajafnréttismenntunina betur inn í starfið á peirra starfsvettvangi.

\section{Ályktanir og lokaorð}

Markmið rannsóknarinnar var að kanna hvernig staðið væri að kynjajafnréttismenntun með elstu börnum í leikskólunum sex. Talsverð kynjajafnréttismenntun fór fram í leikskólunum sex en hún virtist í flestum tilvikum vera hád áhuga hvers og eins leikskólakennara, og í mörgum tilfellum var hún ómeðvituð. Flestir leikskólakennaranna, sem rætt var við, voru óöruggir en töldu að peir ynnu líklega minna með pennan pátt menntunar en nauðsynlegt væri. Petta kann að stafa af pekkingarleysi á kynjafræðilegum hugtökum, hvað felst í kynjajafnréttismenntun og hvaða áhrif staðalímyndir geta haft á mótun barna. Jafnvel pótt slíkum staðalímyndum hafi stundum verið ögrað í starfinu, pá virtist pað ekki gert á skipulegan hátt.

Hægt er að álykta út frá peim gögnum, sem unnið var með, að kynjajafnréttismenntun hafi verið fremur ómarkviss í pessum sex leikskólum. Sama niðurstaða kom fram í meistaraprófsrannsókn Laufeyjar Heimisdóttur (2018) um að kennarar og starfsfólk ,segjast hafa jafnrétti í huga, grípa tækifærin pegar pau skapast og nota umræður til pess að leiðbeina nemendum“ (bls. 60). Hins vegar virðist að mörgu leyti sé góður jarðvegur fyrir kynjajafnréttisfræðsluna og áhugi og sprotastarf til staðar, til dæmis í vali á leikefni. Sú hugmynd var einnig til staðar að grípa tækifærið pegar pað gæfist.

Rannsakendur taka undir ábendingar Porgerðar Einarsdóttur og Ingólfs Ásgeirs Jóhannessonar (2011) um að mikilvægt sé að efla stofnanalega ábyrgðá kynjajafnréttismenntun barna, ípessu tilviki bæði skóla og sveitarfélaga. Undir petta taka raunar skólastjórar leikskóla og annarra skólastiga sem tóku pátt í rannsókn Guðnýjar S. Guðbjörnsdóttur og Steinunnar Helgu Lárusdóttur (2017). Kreitz-Sandberg (2016) lagði einnig áherslu á mikilvægi pess að præða hugtök kynjafræðinnar inn í nám kennaranema á sem fjölbreyttastan máta, svo að pað yrði peim eðlislægt að beita peim í starfi. Dorgerður og Ingólfur halda pví fram að próunarverkefni hafi tilhneigingu til að gufa upp pegar formlegri áætlun um pau lýkur. Guðný og Steinunn Helga benda jafnframt á að jafnréttisáætlun eða fræðslufundir um jafnréttismál, sem ekki sé fylgt eftir, pjóni takmörkuðum tilgangi.

Að mati höfunda felst grundvöllurinn fyrir eflingu kynjajafnréttismenntunar í leikskólunum í rækilegum stuðningi við kennarana. Fræðslan sem fer fram með pví að grípa tækifærin í daglegu starfi er mikilvæg, og hægt er að styrkja kennarana í pví hvernig peim inngripum er háttað. Раð ætti pó einnig að leiðbeina skólunum um skipulag starfsins pannig að kynjajafnréttismenntuninni væri stöðugt fléttað inn í. Kennararnir og ekki síður hið ófaglærða starfsfólk leikskólanna parf 
fræðslu, sem getur verið bæði formleg og óformleg. Раð er femínískt verkefni að draga fram í dagsljósið pað sem vel er gert og benda á mikilvægi pess anga jafnréttis í íslensku samfélagi, bæði í samtíma og fyrir framtíðina.

\section{Aftanmálsgreinar}

1. Í pessum opinberu textum er einungis minnst á tvö kyn, karla og konur (drengi og stúlkur). Efni lagagreina og aðalnámskrár um til dæmis staðalímyndir og hlutverk á ekki síður við pegar litið er svo á að kyn geti verið fleiri en tvö, pað er að staðalímyndir eiga líklega snaran pátt í að treysta í sessi hugmyndina um einungis tvö kyn.

2. Nákvæmari greinargerð um pátttakendur og aðferðir við greiningu er í meistaraprófsrannsókn Sólveigar Bjargar Pálsdóttur (2019).

\section{Always somehow in the back of the mind. Gender equality education in preschools}

The aim of the study was to explore the practice of gender equality education in the oldest age groups in Icelandic preschools. Seven preschool teachers in six preschools in the capital city area were interviewed, and the researcher conducted around three hours of observation in each of the schools to gain insight into classroom practice. The sample of schools and teachers was determined by employing a stratified random sampling, from different parts of Reykjavík and its surrounding towns. The interviews were rich in content and observations insightful into daily operations at the preschools.

The findings are reported here in three thematic groups. The first group contains four main themes: How the children dress, role models, stereotypes about sex roles, and gender division. The interviewees reported on the ways in which the gendered and gender-divided society tends to be reflected in preschool operations. This appears, for example, in the gendered dress code of the children which may be influenced by popular children's television programs. The preschool teachers were critical of gender stereotypes in society, and they expressed the view that if more men worked in preschools, a greater variety of role models would be presented to the children. The preschool teachers were also critical of how gender was constructed among the children and argued that they had the role of fostering critical thinking in the children.

The second group comprises six themes: Books, what appeared on the walls, blocks, jigsaw puzzles, role play, and rough and tumble play. The interviewees emphasized the importance of scrutinizing books according to the type of gender images and stereotypes they present. When posters and wall art in the schools were examined, examples of stereotypes were not typical. The blocks were considered to be gender divided-toys in spite of being "unbelievably ungendered phenomena", as one of the teachers put it. In their experience, boys played more with blocks than girls did. The teachers are conscious of gendered toys, such as Barbie or "princess jigsaw puzzles" or "car jigsaw puzzles" and tried to encourage children to cross boundaries that assign certain toys to one gender.

In the third group, there are three themes that concern the preparation and situation of preschool teachers; gender equality policy, and the call for gender equality education for teachers, and for other staff. It was under this umbrella that the title of the article 
appeared: that gender equality education is "always somehow in the back of the mind; that is, opportunities were taken when they arose. We asked about gender equality policy documents which apparently exist in the municipalities. Teachers and other staff do not seem have been informed about the content of such policies. One of the teachers suggested that educational material, "packages", should be prepared for the preschools to apply in their practice, and other teachers reported that staff development seemed to focus on issues unrelated to gender.

Although we witnessed positive examples in relation to gender equality work, the overall conclusion is that work promoting gender equality education in the six preschools was scarce and coincidental, and most often not preplanned. But we noted a keen interest, among teachers, and in some of the schools, in selecting appropriate play materials. We believe it is vital that municipal and other authorities assume institutional responsibility for gender equality education. Furthermore, the preschools need a high level of support for enhancing this area of practice. This does not only apply to preschool teachers but also to other staff in the preschools who do not have professional education. And although this an educational responsibility, we also argue that it is a feminist project to identify what is of value in the current activities and to enhance this important aspect of Icelandic society, currently and for the future.

Key words: Gender, sex roles, preschools, stereotypes.

\section{Um höfundana}

Sólveig Björg Pálsdóttir (solveig.bjorg.palsdottir@rvkskolar.is) er leikskólakennari í Laugasól, Reykjavík. Hún lauk BA-prófi í sagnfræði 2013 og M.Ed.-prófi í menntunarfræði leikskóla 2019, báđum prófunum frá Háskóla Íslands. Hún hefur brennandi áhuga á kynjajafnréttisfræðslu ungra barna og að efla pann námspátt í leikskólastarfi á Íslandi.

Ingólfur Ásgeir Jóhannesson (ingo@hi.is) er prófessor við Menntavísindasvið Háskóla Íslands. Hann lauk bakkalárprófi í sagnfræði og uppeldisfræði 1979, námi til kennsluréttinda 1980 og cand.mag.-prófi í sagnfræði 1983 frá Háskóla Íslands, og doktorsprófi í menntunarfræðum 1991 frá Wisconsinháskóla, Madison. Sérsvið hans eru menntastefna, námskrár og kynjafræði í menntarannsóknum.

\section{About the authors}

Sólveig Björg Pálsdóttir (solveig.bjorg.palsdottir@rvkskolar.is) is a preschool teacher at Laugasól preschool in Reykjavík. She completed her B.A. degree in history in 2013 and an M.Ed. degree in preschool educational studies in 2019, both degrees from the University of Iceland. She has a special interest in gender equality education with young children and in enhancing this particular aspect of education in Icelandic preschools.

Ingólfur Ásgeir Jóhannesson (ingo@hi.is) is a professor at the School of Education, University of Iceland. He completed his B.A. degree in history and educational studies in 1979, a post-graduate diploma for a teaching certificate in 1980, a cand.mag. degree in history in 1983, all from the University of Iceland, as well as a Ph.D. degree in curriculum and instruction from the University of Wisconsin, Madison, in 1991. His research focuses on education policy, curriculum, and gender and education. 


\section{Heimildir}

Eiginnöfn allra höfunda eru skráð í heimildaskránni, íslenskra í eðlilegri stafrófsröð, en erlendra á eftir kenninafninu. Petta er gert til pess að vekja athygli á kvenhöfundum par sem eitt af markmiðum femínista er að gera konur sýnilegri (Rannveig Traustadóttir, 2013).

Anna Elísa Hreiðarsdóttir. (2018). Ævintýralegt jafnrétti: Starfendarannsókn í leikskóla. Netla - Veftímarit um uppeldi og menntun. Sótt af http://netla.hi.is/greinar/2018/ryn/04.pdf

Arna H.Jónsdóttir, Steinunn H. Lárusdóttir og Dórdís Pórðardóttir. (2005). Kynjamyndir í skólastarfi. Reykjavík: Rannsóknarstofnun Kennaraháskóla Íslands.

Arnfríður Aðalsteinsdóttir [verkefnisstjóri]. (2010). Jafnréttisfræðsla í leik- og grunnskólum: Skýrsla um próunarverkefni 2008-2009. Sótt af https://www.jafnretti.is/static/files/2018/lokaskyrsla-jafnrettisfraedsla.pdf

Butler, Judith. (1990). Gender trouble: Feminism and the subversion of identity. London: Routledge.

Connell, Raewyn. (2006). Understanding men: Gender sociology and the new international research on masculinities. Í Christine Skelton, Becky Francis og Lisa Smulyan (ritstýrur), The Sage handbook on gender and education (bls. 18-31). London: Sage.

Emilson, Anette; Folkesson, Anne-Mari og Lindberg, Ingeborg Moqvist. (2016). Gender beliefs and embedded gendered values in preschool. International Journal of Early Childhood, 48(2), 225-240. doi:10.1007/ s13158-016-0162-4

Foucault, Michel. (1972). The archaeology of knowledge (A. M. Sheridan Smith pýddi). New York: Harper \& Row.

Francis, Becky. (2006). The nature of gender. Í Christine Skelton, Becky Francis og Lisa Smulyan (ritstýrur), The Sage handbook on gender and education (bls. 7-18). London: Sage.

Guðný S. Guðbjörnsdóttir og Steinunn Helga Lárusdóttir. (2017). Hvernig er tekið á fræðslu um kynjajafnrétti í skólum? Athugun á viðhorfum, pekkingu og áhuga skólastjóra priggja skólastiga. Netla - Veftímarit um uppeldi og menntun. Sótt af http://netla.hi.is/greinar/2017/ryn/17.pdf

Guðný S. Guðbjörnsdóttir og Pórdís Pórðardóttir. (2016). Kynjajafnrétti og kennaramenntun:Ákall kennaranema um aukna fræðslu. Netla - Veftímarit um uppeldi og menntun. Sótt af http://netla.hi.is/greinar/2016/ ryn/10_ryn_arsrit_2016.pdf

Guðrún Alda Harðardóttir og Gyða Margrét Pétursdóttir. (2014). Gendering in one Icelandic preschool. Journal of Nordic Early Childhood Education Research, 7(9), 1-14.

Gyða Margrét Pétursdóttir. (2012). Styðjandi og mengandi kvenleiki innan áru kynjajafnréttis. Íslenska pjóðfélagið, 3, 5-18.

Hjallastefnan. (e.d.). Algengar spurningar. Sótt af https://www.hjalli.is/q_n_a/

Hyun, Eunsook og Choi, Dong Haw. (2004). Examination of young children's gender-doing and genderbending in their play dynamics: A cross cultural exploration. International Journal of Early Childhood, 36(1), 49-64. doi:10.1007/BF03165940

Ingólfur Ásgeir Jóhannesson. (2004). Karlmennska og jafnréttisuppeldi. Reykjavík: Rannsóknarstofa í kvennaog kynjafræðum við Háskóla Íslands.

Jóhanna Kr. Jónsdóttir. (2015). Nú skal segja ... Próunarverkefni um jafnrétti kynjanna í leikskólanum Geislabaugi. Sótt af http://geislabaugur.is/images/nu_skal_segja_throunarverkefni_i_leikskolanum_Geislabaugi.pdf

Kreitz-Sandberg, Susanne. (2016). Improving pedagogical practices through gender inclusion. International Journal for Research on Extended Education, 4(2), 71-91. doi:10.3224/ijree.v4i2.25782

Kristín Dýrfjörð, Dórður Kristinsson og Berglind Rós Magnúsdóttir. (2013).Jafnrétti: Grunnpáttur í menntun á öllum skólastigum. Reykjavík: Mennta- og menningarmálaráduneytið og Námsgagnastofnun.

Kristín Loftsdóttir. (2013). Vettvangsrannsóknir. Í Sigríður Halldórsdóttir (ritstýra), Handbók í aðferðafreði rannsókna (bls. 327-336). Akureyri: Háskólinn á Akureyri.

Laufey Axelsdóttir og Gyða Margrét Pétursdóttir. (2014). Kynjaðar væntingar til kvenna og karla í tveimur leikskólum. Netla - Veftímarit um uppeldi og menntun. Sótt af http://netla.hi.is/greinar/2014/ryn/002.pdf

Laufey Heimisdóttir. (2018). Jafnréttismenntun í tveimur leikskólum: Sjónarmið starfsfólks, stjórnenda og mikilvagi umhverfis (óútgefin meistaraprófsritgerð). Menntavísindasvið Háskóla Íslands, Reykjavík. 
Lichtman, Marilyn. (2013). Qualitative research in education: A user's guide. London: Sage.

Lög um jafna stöðu og jafnan rétt kvenna og karla nr. 10/2008.

Margrét Pála Ólafsdóttir. (1992). Efingin skapar meistarann: Leikskóli fyrir stelpur og stráka. Reykjavík: Mál og menning.

Meland, Aud Torill og Kaltved, Elsa Helen. (2017). Tracking gender in kindergarten. Early Child Development and Care, 189(1), 94-103. doi:10.1080/03004430.2017.1302945

Mennta- og menningarmálaráđuneytið. (2012). Aðalnámskrá leikskóla 2011. Reykjavík: Höfundur.

Merriam, Sharan B. (2009). Doing qualitative research: A guide to design and implementation. San Francisco:Jossey Bass.

Rannveig Traustadóttir. (2013). Femínískar rannsóknir. Í Sigríður Halldórsdóttir (ritstýra), Handbók í aðferðafraði rannsókna (bls. 313-325). Akureyri: Háskólinn á Akureyri.

Ropers-Huilman, Rebecca og Winters, Kelly T. (2011). Feminist research in higher education. The Journal of Higher Education, 86(6), 667-690. doi:10.1080/00221546.2011.11777223

Sandström, Margareta; Stier, Jonas og Sandberg,Anette. (2013). Working with gender pedagogics at 14 Swedish preschools. Journal of Early Childhood Research, 11(2), 123-132. doi:10.1177/1476718X12466205

Schippers, Mimi. (2007). Recovering the feminine other: Masculinity, femininity, and gender hegemony. Theory, Culture and Society, 36(1), 85-102. doi:10.1007/s11186-007-9022-4

Sigurður Kristinsson. (2013). Siðfræði rannsókna og siðanefndir. Í Sigríður Halldórsdóttir (ritstýra), Handbók i aðferðafreði rannsókna (bls. 71-88). Akureyri: Háskólinn á Akureyri.

Sólveig Karvelsdóttir. (2005). Pau kunna mannganginn. Í Arna H. Jónsdóttir, Steinunn H. Lárusdóttir og Dórdís Pórðardóttir (ritstýrur), Kynjamyndir í skólastarfi (bls. 85-101). Reykjavík: Rannsóknarstofnun Kennaraháskóla Íslands.

Sólveig Björg Pálsdóttir. (2019). „Detta er kannski alltaf svoncea á bak við eyrað“. Kynjajafnréttismenntun elstu barna í sex leikskólum (óútgefið meistaraprófsverkefni). Háskóli Íslands, Reykjavík.

Warin, Jo og Adriany,Vina (2015). Gender flexible pedagogy in early childhood education. Journal of Gender Studies, 25(4), 375-386. doi:10.1080/09589236.2015.1105738

Dorgerður Einarsdóttir og Ingólfur Ásgeir Jóhannesson. (2011). Kynjajafnréttisfræðsla í skólum: Hindranir og tækifæri. Rádstefnurit Netlu - Menntakvika 2011. Sótt af http://netla.hi.is/menntakvika2011/030.pdf

Dórdís Dórðardóttir. (2012).Að læra til telpu og drengs. Rádstefnurit Netlu-Menntakvika 2012. Sótt af http:// netla.hi.is/menntakvika2012/016.pdf

Dórdís Pórðardóttir. (2015).Virðingarsess leikskólabarna: Pekking á barnaefni, kynjun og lagskipting í tveimur leikskólum. Netla - Veftímarit um uppeldi og menntun. Sótt af http://netla.hi.is/greinar/2015/ryn/001.pdf

Pórólfur Pórlindsson og Porlákur Karlsson. (2013). Úrtök og úrtaksaðferðir í megindlegum rannsóknum. Í Sigríður Halldórsdóttir (ritstýra), Handbók í aðferðafraði rannsókna (bls. 113-128). Akureyri: Háskólinn á Akureyri.

Sólveig Björg Pálsdóttir og Ingólfur Ásgeir Jóhannesson. (2020).

„Kannski alltaf svona á bak við eyrað“: Kynjajafnréttismenntun í leikskólum

Netla - Veftímarit um uppeldi og menntun. Menntavísindasvið Háskóla Íslands.

Sótt af http://netla.hi.is/greinar/2020/ryn/01

DOI: https://doi.org/10.24270/netla.2020.1 